\title{
Front Matter: Volume 11250
}

, "Front Matter: Volume 11250," Proc. SPIE 11250, High-Speed Biomedical Imaging and Spectroscopy V, 1125001 (5 March 2020); doi:

$10.1117 / 12.2569573$

SPIE. Event: SPIE BiOS, 2020, San Francisco, California, United States 


\section{PROGRESS IN BIOMEDICAL OPTICS AND IMAGING}

\section{High-Speed Biomedical Imaging and Spectroscopy $V$}

Kevin K. Tsia

Keisuke Goda

Editors

1-4 February 2020

San Francisco, California, United States

Sponsored and Published by

SPIE 
The papers in this volume were part of the technical conference cited on the cover and title page. Papers were selected and subject to review by the editors and conference program committee. Some conference presentations may not be available for publication. Additional papers and presentation recordings may be available online in the SPIE Digital Library at SPIEDigitalLibrary.org.

The papers reflect the work and thoughts of the authors and are published herein as submitted. The publisher is not responsible for the validity of the information or for any outcomes resulting from reliance thereon.

Please use the following format to cite material from these proceedings:

Author(s), "Title of Paper," in High-Speed Biomedical Imaging and Spectroscopy V, edited by Kevin K. Tsia, Keisuke Goda, Proceedings of SPIE Vol. 11250 (SPIE, Bellingham, WA, 2020) Seven-digit Article CID Number.

ISSN: 1605-7422

ISSN: 2410-9045 (electronic)

ISBN: 9781510632639

ISBN: 9781510632646 (electronic)

Published by

SPIE

P.O. Box 10, Bellingham, Washington 98227-0010 USA

Telephone +13606763290 (Pacific Time) · Fax +1 3606471445

SPIE.org

Copyright (c) 2020, Society of Photo-Optical Instrumentation Engineers.

Copying of material in this book for internal or personal use, or for the internal or personal use of specific clients, beyond the fair use provisions granted by the U.S. Copyright Law is authorized by SPIE subject to payment of copying fees. The Transactional Reporting Service base fee for this volume is $\$ 21.00$ per article (or portion thereof), which should be paid directly to the Copyright Clearance Center (CCC), 222 Rosewood Drive, Danvers, MA 01923. Payment may also be made electronically through CCC Online at copyright.com. Other copying for republication, resale, advertising or promotion, or any form of systematic or multiple reproduction of any material in this book is prohibited except with permission in writing from the publisher. The CCC fee code is $1605-$ $7422 / 20 / \$ 21.00$.

Printed in the United States of America by Curran Associates, Inc., under license from SPIE.

Publication of record for individual papers is online in the SPIE Digital Library.

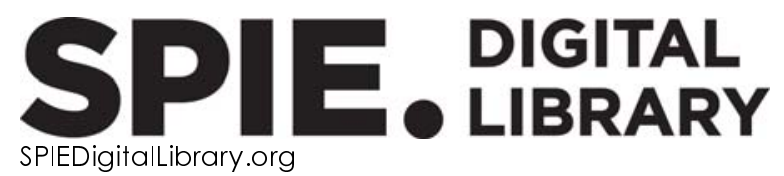

Paper Numbering: Proceedings of SPIE follow an e-First publication model. A unique citation identifier (CID) number is assigned to each article at the time of publication. Utilization of CIDs allows articles to be fully citable as soon as they are published online, and connects the same identifier to all online and print versions of the publication. SPIE uses a seven-digit CID article numbering system structured as follows:

- The first five digits correspond to the SPIE volume number.

- The last two digits indicate publication order within the volume using a Base 36 numbering system employing both numerals and letters. These two-number sets start with 00, 01, 02, 03, 04, 05, 06, 07, 08, 09, OA, OB ... 0Z, followed by 10-1Z, 20-2Z, etc. The CID Number appears on each page of the manuscript. 


\section{Contents}

$\begin{array}{ll}\text { iii } & \text { Authors } \\ \text { iv } \quad \text { Conference Committee }\end{array}$

HIGH-THROUGHPUT MICROSCOPY

$11250 \mathrm{OE} \quad$ High-throughput and field-portable ptychographic lensless on-chip microscopy based on translated pattern modulation [11250-12]

IMAGING FLOW CYTOMETRY

$11250 \mathrm{OH} \quad$ 2D image-guided cell sorter and 3D imaging flow cytometer (Invited Paper) [11250-15]

11250 J Image-based cell sorting using artificial intelligence [1 1250-17]

HIGH-THROUGHPUT BIOLOGY

11250 ON Probing the spatiotemporal dynamics of Ras-associated membrane nanodomains with highthroughput single particle tracking via photoactivated localization microscopy (spt-PALM) (Invited Paper) [1 1250-21]

11250 OP High-speed label-free photoacoustic histopathology [1 1250-23]

HIGH-THROUGHPUT TECHNOLOGIES

$11250 \mathrm{OZ} \quad$ Acquiring fluorescence decay kinetic measurements with on-chip acoustic focusing cytometry (Invited Paper) [1 1250-33]

1125012 Continuous high-resolution observation system using high-speed gaze and focus control with wide-angle triangulation [1 1250-36] 
Proc. of SPIE Vol. 11250 1125001-4 Downloaded From: https://www.spiedigitallibrary.org/conference-proceedings-of-spie on 26 Apr 2023
Terms of Use: https://www.spiedigitallibrary.org/terms-of-use 


\section{Authors}

Numbers in the index correspond to the last two digits of the seven-digit citation identifier (CID) article numbering system used in Proceedings of SPIE. The first five digits reflect the volume number. Base 36 numbering is employed for the last two digits and indicates the order of articles within the volume. Numbers start with 00, 01, 02, 03, 04, 05, 06, 07, 08, 09, 0A, 0B...0Z, followed by 10-1Z, 20-2Z, etc.

Abuhattum, Shada, 0J

Baik, Jin Woo, OP

Bian, Zichao, OE

Byun, Kyunghee, OP

Chen, Jiajie, $\mathrm{OH}$

Chen, Xinyu, $\mathrm{OH}$

Cho, Sung Hwan, $\mathrm{OH}$

Choi, Hae Young, OP

Gagne, Ivan, $\mathrm{OH}$

Girardo, Salvatore, 0J

Goswami, Ruchi, 0J

$\mathrm{Gu}, \mathrm{Yi}, \mathrm{OH}$

Guck, Jochen, OJ

Guo, Chengfei, OE

Han, Yuanyuan, $\mathrm{OH}$

Herbig, Maik, $0 \mathrm{~J}$

Herold, Christoph, 0J

Houston, Jessica P., $\mathrm{OZ}$

Huang, Tao, ON

Ishikawa, Masatoshi, 12

Jacobi, Angela, 0J

Jiang, Shaowei, OE

Kim, Chulhong, OP

Kim, Hyojin, OP

Kim, Jin Young, OP

Kräter, Martin, OJ

Kubankova, Marketa, OJ

Lee, Chang-Hung, $\mathrm{OH}$

Lee, Yerim, ON

Lo, Yu-Hwa, OH

Mostofian, Barmak, ON

Müller, Paul, OJ

Nan, Xiaolin, ON

Nawaz, Ahmad Ahsan, 0J

Nötzel, Martin, 0J

Ogawa, Takuya, 12

Phelps, Carey, oN

Reichel, Felix, 0J

Rosendahl, Philipp, 0J

Ryu, Seon Young, OP

Sambrano, Jesus, $\mathrm{OZ}$

Son, Myeongjoo, OP

Song, Pengming, OE

Sueishi, Tomohiro, 12

Tang, Rui, $\mathrm{OH}$

Tao, Kai, ON

Taubenberger, Anna, 0J

Töpfner, Nicole, 0J

Urbanska, Marta, OJ
Waller, Lauren, $\mathrm{OH}$

Wang, Ruihai, OE

Yachida, Shoji, 12

Zhang, Alex $\mathrm{Ce}, \mathrm{OH}$

Zhang, $\mathrm{He}, \mathrm{OE}$

Zhang, Zunming, $\mathrm{OH}$

Zheng, Guoan, OE

Zhu, Jiakai, OE

Zuckerman, Daniel, ON 
Proc. of SPIE Vol. 11250 1125001-6 Downloaded From: https://www.spiedigitallibrary.org/conference-proceedings-of-spie on 26 Apr 2023
Terms of Use: https://www.spiedigitallibrary.org/terms-of-use 


\title{
Conference Committee
}

\author{
Symposium Chairs
}

Jennifer K. Barton, The University of Arizona (United States)

Wolfgang Drexler, Medizinische Universität Wien (Austria)

Program Track Chairs

Ammasi Periasamy, University of Virginia (United States)

Daniel L. Farkas, University of Southern California (United States) and SMI (United States)

\section{Conference Chairs}

Kevin K. Tsia, The University of Hong Kong (Hong Kong, China)

Keisuke Goda, The University of Tokyo (Japan)

\section{Conference Program Committee}

Steven G. Adie, Cornell University (United States)

Mohammad Hossein Asghari, Loyola Marymount University (United States)

Hongwei Chen, Tsinghua University (China)

Pei-Yu Eric Chiou, University of California, Los Angeles (United States)

Shi-Wei Chu, National Taiwan University (Taiwan)

Meng Cui, Purdue University (United States)

Qionghai Dai, Tsinghua University (China)

Mark Foster, Johns Hopkins University (United States)

Katsumasa Fujita, Osaka University (Japan)

Liang Gao, University of Illinois at Urbana-Champaign (United States)

Nobuyuki Hashimoto, Citizen Watch Co., Ltd. (Japan)

Elena Holden, Executive Strategic Advisory, Biotech and IVD (United States)

Bahram Jalali, University of California, Los Angeles (United States)

Chulhong Kim, Pohang University of Science and Technology (Korea, Republic of)

Thomas Klein, Optores GmbH (Germany)

Edmund Y. Lam, The University of Hong Kong (Hong Kong, China)

Cheng Lei, Wuhan University (China)

Tzu-Ming Liu, University of Macau (Macao, China)

Yu-Hwa Lo, University of California, San Diego (United States)

Hideharu Mikami, The University of Tokyo (Japan)

Nao Nitta, CYBO, Inc. (Japan)

Yasuyuki Ozeki, The University of Tokyo (Japan) 
YongKeun Park, KAIST (Korea, Republic of)

Adrian Podoleanu, University of Kent (United Kingdom)

Dario Polli, Politecnico di Milano (Italy)

Eric O. Potma, University of California, Irvine (United States)

Peter T. C. So, Massachusetts Institute of Technology (United States)

Lei Tian, Boston University (United States)

Laura Waller, University of California, Berkeley (United States)

Chao Wang, University of Kent (United Kingdom)

Lihong V. Wang, Caltech (United States)

Kenneth Y. Wong, The University of Hong Kong (Hong Kong, China)

Takeshi Yasui, Tokushima University (Japan)

Tomokazu Yoshida, Sysmex Corporation (Japan)

Zeev Zalevsky, Bar-llan University (Israel)

\section{Session Chairs}

1 High-Speed Volumetric Imaging

Kevin K. Tsia, The University of Hong Kong (Hong Kong, China)

2 High-Speed Fluorescence Imaging

Adrian G. H. Podoleanu, University of Kent (United Kingdom)

3 High-Throughput Microscopy

Meng Cui, Purdue University (United States)

$4 \quad$ Imaging Flow Cytometry

Keisuke Goda, The University of Tokyo (Japan)

5 High-Throughput Biology

Liang Gao, University of Illinois (United States)

6 High-Speed Raman Technologies

Eric O. Potma, University of California, Irvine (United States)

$7 \quad$ Machine Learning

Kotaro Hiramatsu, The University of Tokyo (Japan)

8 High-Throughput Technologies

Guoan Zheng, University of Connecticut (United States)

9 Quantitative Phase Imaging and High-Speed Biomedical Imaging and Spectroscopy: Joint Session with 11249 and 11250

Yang Liu, University of Pittsburgh (United States)

Kevin K. Tsia, The University of Hong Kong (Hong Kong, China) 